\title{
Acute-onset postoperative endophthalmitis caused by multidrug-resistant Klebsiella pneumoniae
}

\author{
This article was published in the following Dove Press journal: \\ Clinical Ophthalmology \\ 16 September 2014 \\ Number of times this article has been viewed
}

\author{
Shekhar Sanghi' \\ Avinash Pathengay' \\ Animesh Jindal' \\ Vishal Raval ${ }^{2}$ \\ Sameera Nayak ${ }^{2}$ \\ Savitri Sharma ${ }^{3}$ \\ Abhishek Bawdekar' \\ Harry W Flynn Jr ${ }^{4}$ \\ 'Department of Ophthalmology, \\ LV Prasad Eye Institute, GMR \\ Varalakshmi Campus, Visakhapatnam, \\ Andhra Pradesh, India; ${ }^{2}$ Department \\ of Ophthalmology, LV Prasad Eye \\ Institute, KVC Campus, Vijayawada, \\ Andhra Pradesh, India; ${ }^{3}$ Department \\ of Microbiology, Jhaveri Microbiology \\ Centre, LV Prasad Eye Institute, KAR \\ Campus, Hyderabad, Andhra Pradesh, \\ India; ${ }^{4}$ Department of Ophthalmology, \\ Bascom Palmer Eye Institute, Miller \\ School of Medicine, University \\ of Miami, Miami, FL, USA
}

\begin{abstract}
The purpose of this paper is to report outcomes of intravitreal imipenem in the treatment of multidrug-resistant Klebsiella-related postoperative endophthalmitis. This observational case series consists of three eyes from three patients seen between 2013 and 2014 . Multidrug-resistant Klebsiella pneumoniae is characterized by a rapid, fulminant course and severe intraocular inflammation. Intravitreal imipenem may be used to treat such infection.

Keywords: postoperative endophthalmitis, Klebsiella pneumoniae, imipenem, multidrug resistance

\section{Introduction}

Acute-onset postoperative endophthalmitis is characterized by marked inflammation of intraocular fluids and tissues. Gram-negative bacteria are less commonly isolated than Gram-positive bacteria in patients with acute-onset postoperative endophthalmitis. Gram-negative organisms have been isolated in $26 \%-42 \%$ of patients with cataract surgery related to endophthalmitis in developing countries, ${ }^{1,2}$ as compared with $5.9 \%-11.8 \%$ in developed countries. ${ }^{3}$ The more common Gram-negative organisms causing endophthalmitis include species of Pseudomonas, Haemophilus, Proteus, and Klebsiella. There have been reports of multidrug-resistant strains of Gram-negative bacteria being isolated from patients with endophthalmitis. ${ }^{4}$ Endophthalmitis caused by Klebsiella pneumoniae is associated with generally poor visual outcomes, despite treatment with appropriate antibiotics. ${ }^{5}$ Three cases of acute postoperative endophthalmitis due to multidrug-resistant $K$. pneumoniae are reported.
\end{abstract}

\section{Case reports}

Three patients developed acute-onset endophthalmitis within 1-3 days following cataract surgery (Table 1). All the patients were in good general health and were not known to be suffering from any known systemic illness in the pre and postoperative periods. Presenting visual acuity ranged from 20/50 to light perception. Hypopyon was observed in all patients and corneal infiltrate was observed in two patients who presented with visual acuity of light perception.

One patient underwent vitreous tap with intraocular injection of vancomycin $1 \mathrm{mg} / 0.1 \mathrm{~mL}$, amikacin $400 \mu \mathrm{g} / 0.1 \mathrm{~mL}$, and dexamethasone $400 \mu \mathrm{g} / 0.1 \mathrm{~mL}$. The other two patients underwent pars plana vitrectomy with intravitreal injection of the aforementioned antibiotics and dexamethasone. Gram-negative bacilli were isolated and confirmed to be $K$. pneumoniae by Vitek 2 compact (bioMérieux, France). Antibiotic
Correspondence: Avinash Pathengay Department of Ophthalmology, L V Prasad Eye Institute, GMR Varalakshmi Campus, Visakhapatnam, Andhra Pradesh 530040, India Tel +91 9989156789

Email avinash@lvpei.org 
Table I Intervention and visual outcome of multidrug-resistant Klebsiella endophthalmitis

\begin{tabular}{|c|c|c|c|c|c|c|c|c|}
\hline Case & Eye & $\begin{array}{l}\text { Presenting } \\
\text { visual acuity }\end{array}$ & $\begin{array}{l}\text { Primary } \\
\text { intervention }\end{array}$ & $\begin{array}{l}\text { Number of } \\
\text { intravitreal } \\
\text { imipenem } \\
\text { injections }\end{array}$ & $\begin{array}{l}\text { Intraocular } \\
\text { explantation }\end{array}$ & $\begin{array}{l}\text { Final visual } \\
\text { acuity }\end{array}$ & Outcome & Follow-up \\
\hline I & OS & $20 / 50$ & $\begin{array}{l}\text { Vitreous biopsy + } \\
\text { IOAB }(V+A)\end{array}$ & 2 & Yes & LP, PR inaccurate & Phthisis & 7 months \\
\hline 2 & OS & LP, PR accurate & $P P V+I O A B(V+A)$ & 2 & No & LP, PR inaccurate & Optic atrophy & 4 months \\
\hline 3 & OD & LP, PR inaccurate & $\begin{array}{l}\text { PPV }+ \text { IOL explant }+ \\
\text { IOAB }(V+A)\end{array}$ & 2 & Yes & NLP & Phthisis & I month \\
\hline
\end{tabular}

Abbreviations: A, amikacin; IOAB, intraocular antibiotic; IOL, intraocular lens; LP, perception of light; NLP, no perception of light; OD, right eye; OS, left eye; PPV, pars plana vitrectomy; PR, projection of rays; $\mathrm{V}$, vancomycin.

susceptibility testing was determined by the Kirby-Bauer disk diffusion method (Table 2).

All isolates were multidrug resistant (Table 2) and were sensitive to imipenem. The organism that was isolated in case 3 was also found to be sensitive to ceftazidime and colistin.

Clinical deterioration was observed in all patients 2-3 days after initial intervention. Additional procedures in the form of pars plana vitrectomy with intravitreal injection of imipenem $50 \mu \mathrm{g} / 0.1 \mathrm{~mL}$ were carried out in all patients. Since there was no improvement 2 days after the second intervention, all patients were reinjected with intravitreal imipenem.

At last follow-up, visual acuity was poor in all the patients, there was light perception in two patients, and no light perception in the third patient. Phthisis bulbi occurred in two patients (Table 1).

Table 2 Antibiotic susceptibility patterns of Klebsiella pneumoniae isolates

\begin{tabular}{llll}
\hline Antibiotic & \multicolumn{2}{l}{ Susceptibility } & result \\
\cline { 2 - 4 } & Case I & Case 2 & Case 3 \\
\hline Amikacin & $\mathrm{R}$ & $\mathrm{R}$ & $\mathrm{R}$ \\
Chloramphenicol & $\mathrm{R}$ & $\mathrm{R}$ & $\mathrm{R}$ \\
Ciprofloxacin & $\mathrm{R}$ & $\mathrm{R}$ & $\mathrm{R}$ \\
Gatifloxacin & $\mathrm{R}$ & $\mathrm{R}$ & $\mathrm{R}$ \\
Moxifloxacin & $\mathrm{R}$ & $\mathrm{R}$ & $\mathrm{R}$ \\
Levofloxacin & $\mathrm{R}$ & $\mathrm{R}$ & $\mathrm{R}$ \\
Ceftazidime & $\mathrm{R}$ & $\mathrm{R}$ & $\mathrm{S}$ \\
Ceftriaxone & $\mathrm{R}$ & $\mathrm{R}$ & $\mathrm{R}$ \\
Ceftizoxime & $\mathrm{I}$ & $\mathrm{R}$ & $\mathrm{R}$ \\
Imipenem & $\mathrm{S}$ & $\mathrm{S}$ & $\mathrm{S}$ \\
Azithromycin & $\mathrm{I}$ & $\mathrm{I}$ & $\mathrm{R}$ \\
Co-trimoxazole & $\mathrm{R}$ & $\mathrm{R}$ & $\mathrm{R}$ \\
Colistin & $\mathrm{R}$ & $\mathrm{R}$ & $\mathrm{S}$ \\
Tetracycline & $\mathrm{R}$ & $\mathrm{R}$ & $\mathrm{R}$ \\
Erythromycin & $\mathrm{R}$ & $\mathrm{R}$ & $\mathrm{R}$ \\
Gentamicin & $\mathrm{R}$ & $\mathrm{R}$ & $\mathrm{R}$ \\
Neomycin & $\mathrm{I}$ & $\mathrm{I}$ & $\mathrm{I}$ \\
\hline
\end{tabular}

Abbreviations: I, intermediate; $R$, resistant; $S$, sensitive.

\section{Discussion}

Multidrug resistance is defined as acquired nonsusceptibility to at least one agent in three or more antimicrobial categories. ${ }^{6}$ Incidences of multidrug-resistant Gram-negative bacilli have been increasing in tertiary care hospitals. ${ }^{7}$ It was reported that $5.2 \%$ of microbiological isolates from endophthalmitis patients were multidrug resistant, and $78.6 \%$ of those isolates were Gram-negative bacteria. ${ }^{4}$

The various mechanisms contributing to virulence of K. pneumoniae are the presence of capsular $\mathrm{K} 1 / \mathrm{K} 2$ serotypes, hypermucoviscosity, and the presence of the $\operatorname{mag} A$ gene and the $b l a_{N D M-l}$ gene, which is a carbapenemase $\beta$-lactamase. ${ }^{7-9}$ These bacteria can be resistant to all currently available antimicrobial agents or remain susceptible only to older, potentially more toxic agents such as the polymyxins, leaving limited and suboptimal options for treatment. ${ }^{6}$

Intravitreal imipenem has been studied previously in rabbit eyes and has been reported to be nontoxic to retina. ${ }^{10}$ It acts by inhibiting cell wall synthesis of various Gram-positive and Gram-negative bacteria. It is stable to hydrolysis by the common plasmid-mediated $\beta$-lactamases produced by various bacteria and lacks cross-resistance with penicillins and thirdgeneration cephalosporins. ${ }^{11}$ One case series reported use of intravitreal imipenem in the treatment of endophthalmitis caused by Acinetobacter baumannii. The authors reported that despite the use of multiple intravitreal injections of imipenem, the visual outcomes were poor. ${ }^{12}$ Based on reported antimicrobial sensitivity, $50 \mu \mathrm{g} / 0.1 \mathrm{~mL}$ intravitreal imipenem was utilized in all patients in the current series.

K. pneumoniae has been commonly associated with endogenous endophthalmitis. In reported series, most patients have poor visual outcome despite appropriate antibiotic therapy, and the outcomes are usually phthisis and blindness. ${ }^{5,13}$ This may be attributed to the highly virulent organism as well as to delayed recognition of antibiotic resistance and susceptibility. The outcome of patients in the current case 
series was either phthisis or blindness, even after the best possible treatment.

\section{Author contributions}

Shekhar Sanghi carried out the data collection and drafted the manuscript. Avinash Pathengay is one of the treating physicians and also carried out correction of the manuscript. Animesh Jindal, Vishal Raval, Sameera Nayak, and Abhishek Bawdekar are the other treating physicians. Savitri Sharma was the microbiologist. Harry W Flynn Jr corrected the manuscript. All authors contributed toward data analysis, drafting and revising the paper and agree to be accountable for all aspects of the work.

\section{Disclosure}

The authors report no conflicts of interest in this work.

\section{References}

1. Kunimoto DY, Das T, Sharma S, et al. Microbiological spectrum and susceptibility of isolates: part I. Postoperative endophthalmitis. Endophthalmitis Research Group. Am J Ophthalmol. 1999;128(2):240-242.

2. Jindal A, Pathengay A, Mithal K, et al. Microbiologic spectrum and susceptibility of isolates in acute postcataract surgery endophthalmitis: are they same as they were more than a decade ago? Br J Ophthalmol. 2014;98(3):414-416.

3. Benz MS, Scott IU, Flynn HW Jr, Unonius N, Miller D. Endophthalmitis isolates and antibiotic sensitivities: a 6-year review of culture-proven cases. Am J Ophthalmol. 2004;137(1):38-42.
4. Pathengay A, Moreker MR, Puthussery R, et al. Clinical and microbiologic review of culture-proven endophthalmitis caused by multidrugresistant bacteria in patients seen at a tertiary eye care center in southern India. Retina. 2011;31(9):1806-1811.

5. Scott IU, Matharoo N, Flynn HW Jr, Miller D. Endophthalmitis caused by Klebsiella species. Am J Ophthalmol. 2004;138(4):662-663.

6. Magiorakos AP, Srinivasan A, Carey RB, et al. Multidrug-resistant, extensively drug-resistant and pandrug-resistant bacteria: an international expert proposal for interim standard definitions for acquired resistance. Clin Microbiol Infect. 2012;18(3):268-281.

7. O'Fallon E, Pop-Vicas AE, D'Agata EMC. The emerging threat of multidrug-resistant gram-negative organisms in long-term care facilities. J Gerontol A Biol Sci Med Sci. 2009;64(1):138-141.

8. Fung CP, Hu BS, Chang FY, et al. A 5-year study of the seroepidemiology of Klebsiella pneumoniae: high prevalence of capsular serotype $\mathrm{K} 1$ in Taiwan and implication for vaccine efficacy. J Infect Dis. 2000; 181(6):2075-2079.

9. Wiskur BJ, Hunt JJ, Callegan MC. Hypermucoviscosity as a virulence factor in experimental Klebsiella pneumoniae endophthalmitis. Invest Ophthalmol Vis Sci. 2008;49(11):4931-4938.

10. Loewenstein A, Zemel E, Lazar M, Perlman I. Drug induced retinal toxicity in albino rabbits: the effects of imipenem and aztreonam. Invest Ophthalmol Vis Sci. 1993;34(12):3466-3476.

11. Jindal A, Pathengay A, Khera M, et al. Combined ceftazidime and amikacin resistance among Gram-negative isolates in acute-onset postoperative endophthalmitis: prevalence, antimicrobial susceptibilities, and visual acuity outcome. J Ophthalmic Inflamm Infect. 2013;3(1):62.

12. Chen KJ, Hou CH, Sun MH, Lai CC, Sun CC, Hsiao CH. Endophthalmitis caused by Acinetobacter baumannii: report of two cases. J Clin Microbiol. 2008;46(3):1148-1150.

13. Sheu SJ, Kung YH, Wu TT, Chang FP, Horng Y. Risk factors for endogenous endophthalmitis secondary to Klebsiella pneumoniae liver abscess: 20-year experience in Southern Taiwan. Retina. 2011;31(10): 2026-2031.
Clinical Ophthalmology

\section{Publish your work in this journal}

Clinical Ophthalmology is an international, peer-reviewed journal covering all subspecialties within ophthalmology. Key topics include: Optometry; Visual science; Pharmacology and drug therapy in eye diseases; Basic Sciences; Primary and Secondary eye care; Patien Safety and Quality of Care Improvements. This journal is indexed on

Submit your manuscript here: http://www.dovepress.com/clinical-ophthalmology-journal

\section{Dovepress}

PubMed Central and CAS, and is the official journal of The Society of Clinical Ophthalmology (SCO). The manuscript management system is completely online and includes a very quick and fair peer-review system, which is all easy to use. Visit http://www.dovepress.com/ testimonials.php to read real quotes from published authors. 